\author{
VADYM DENYSENKO, \\ Zaporizhia National University (Zaporizhzhia, Ukraine) \\ e-mail: vifuture@gmail.com,ORCID0000-0003-4317-2884
}

\title{
DONETSK FINANCIAL INDUSTRIAL GROUPS CONSOLIDATION AT THE TURN OF THE XXI CENTURY
}

\begin{abstract}
The article investigates the processes of the powerful financial industrial groups emerging in the Donbass region throughout the 1990 -ies. It is stated that Donbass regional significance drastically raised with Ukraine's gaining independence due to fuel resources concentrated in the region and critically important for state fuel and energy supplies. The research specifically focuses upon the miner unions movement, its role in gaining Ukraine's independence, its further evolution and impact it had upon the regional elite formation. The first Donetsk elite's representative to ever acquire a top position in Kyiv was Yuhym Zviahilskiy, the Zasiadko mine's former director. What boosted his rapid promotion was his cooperation with the Ukraine's President Leonid Kuchma seeking allies for his fight with the Dniepropetrovsk clan. The whole variety of the turn-of-thecentury financial industrial groups is arguably divided into the following categories: 1) sourcebased groups (emerging mostly around coal mining and ore extraction industries typical for the Donbass region); 2) defense industry-based groups with former Komsomol and Party leaders in charge; 3 ) groups based on legal and secretive agencies (mostly known for Victor Medvedchuk and Surkis brothers' activities); 4) Pavlo Lazarenko's proto-agrarian clan. The establishment of System Capital Management, Donbass Industrial Union, Altcom corporations is described with direct reference to Rinat Akhmetov, Serhii Taruta, Vitalii Haiduk, Borys Kolesnikov's roles in this process. The genesis of the groups under consideration is specified through their key industrial assets, affiliated banks, legal status, transregional and international expansion. The "old elite" (mostly related to the criminal syndicates) to the "new elite" (based on income legalization through financial industrial groups and international business) generational shift is explored. Three basic stages of Donetsk clan establishment have been identified: 1) the "mafiosi wars" of the first half of the 1990-ies; 2) consolidation and driving the "old guards" out of regional political and economic field (1995 - 1999); 3) the ultimate establishment of financial industrial groups pursuing their own economical and political interests (early 2000-ies). The author argues that continuous fights between the regional mafiosi groups searching for a common spokesman was one of the reasons for "the Donetsk gang's" belated engagement into struggle for political influence and Ukraine's finance and economic markets reallocation.
\end{abstract}

Key word: Donbass; regional elites; financial industrial groups; oligarchs; privatization; Rinat Akhmetov; Serhii Taruta; Borys Kolesnikov.

Introduction

In the early 1990-ies, two social political tendencies delivered through different NGOs, parties and unions issuing opposite demands, could be traced in Donetsk region. While some of the agents supported Ukrainian independence, the others took every action to prevent it. The following 20 years proved to be crucial for the region's transformation. Once almighty Union centre ceased to be, and the powers in Kyiv had to develop key government institutions. The political vacuum provided favorable conditions for the Donetsk clan's subsequent emergence.

Research methods

Within the Ukrainian scientific discourse, Volodymyr Holovko has made the most considerable contribution to the topic with his two monographs describing the financial industrial groups emergence in Ukraine as a whole and in Donbass in particular (Holovko, 2012a; 2012b). Kerstin

ISSN 1728-9343 (Print)

ISSN 2411-3093 (Online)
Zimmer, the Marburg University Sociology Institute fellow, has spent much time directly in the region conducting the "field studies" of the Donets elite (Zimmer, 2006). Taras Kuzio's investigations of Donetsk clan's political affinities should also be mentioned (Kuzio, 2014; 2015).

However, the existing research in the field is limited either by simply stating the fact of Donetsk clan existence or by analyzing some separate financial industrial groups. It is impossible, though, to understand the reasons of the Donetsk elites boost to political dominance in Ukraine (culminating in Victor Yanukovych's presidency) without a thorough analysis of the process of the once fragmented Donbas groups consolidation into a single informal group. This is why our research aims at highlighting both the process of Donetsk financial industrial groups emerging at the turn of the XXI century and their subsequent merging into a unified regional clan. To reach the goal stated, we apply synchronical (studying the Donetsk elite groups at a single point of time), diachronical (coherent exposi-

SKHID No. 6 November-December 2020 
tion of the Donetsk establishment transformations) and comparative (defining similar and opposite traits of the variety of regional influencers) methods.

\section{Results and discussion}

Miner unions are generally recognized as one of the most significant groups directly influencing the Soviet Union collapse and contributing to the gradual democratization of the Donbass region. Donetsk miners' strike of March 1, 1991, initiated by miner unions and immediately supported nation-wide, set its agenda far beyond economic demands. The miners supported the State Sovereignty Declaration of Ukraine, demanded Mykhailo Horbachov's resignation and directly insisted upon declaring Ukraine's state sovereignty. "Surprisingly enough, it is miner unions that act as our Independence's most devoted supporters. - is stated by the popular opinion of the day. - Within a few weeks, the Donbass has become so Ukrainian in spirit that the Lviv people are at risk of dropping the lead in the national liberation movement» (Adamovich, 2009). As a matter of fact, the miner movement turned into a pushing force, a "Donbass voice" for Ukraine's democratization and sovereignty. As such, they had to compete with the powers hindering the sovereignization process and calling the locals to separatism, i.e., by proclaiming the Donetsk region's autonomy within the Ukrainian Soviet Socialist Republic (Donbas Interrukh, August 28, 1991) or Ukraine's federalization ("Donbass Russian-Speaking Population Rights Protection Movement", "Democratic Donbass", Luhansk Regional People's Movement, Luhansk Historical and Cultural Society "The Renaissance" etc.) and up to G.Lytvak, the "Democratic Donbass" leader, proclaiming the Minor Russia Republic (Donetsk and Luhansk regions with the capital in Luhansk) (Adamovich, 2007). However, these claims failed to strike a chord at the moment. The outputs of confrontation were pinned down by the results of the All-Ukrainian Referendum of December 1, 1991, with the vast majority of Donetsk and Luhansk regions population (83,90\% and $83,86 \%$ respectively) supporting the Declaration of Independence of Ukraine

With Ukraine's gaining independence, the Donbass regional significance drastically raised due to fuel resources concentrated in the region and critically important for state fuel and energy supplies. Donetsk and Luhansk regions' actual share in the pan-Ukrainian fuel and energy system was $30,8 \%$ and $32,8 \%$ respectively (Kononov, Kononova, Denshhik, 2001). However, the overall fuel and energy complex efficiency was critically low due to technical and economical backwardness of the majority of its enterprises demanding considerable financial support that could not be granted by Ukraine's state budget under the 1990-ies crisis.

"Getting rid" of this "burden" turned into a matter-ofsurvival issue for the state that gradually shifted from the state-commanded to market economy. The large-scaled restructuration of regional industries initiated by the Cabinet of Ministers of Ukraine in 1995 and followed by dismantling a considerable part of local enterprises, led to heavy staff cuts. The rise of unemployment rates, in its turn, amped up the social tension and pushed the locals

\footnotetext{
${ }^{1}$ Central State Archive of the highest authorities and administration [Центральний державний архів вищих органів влади та управління]. Fund 1. D.28. File 144. S. 6.
}

towards criminality, while the industries forced into bankruptcy gradually fell into the hands of the newly established economic elite, the clan-structured oligarchic groups. These groups were, in fact, a sort of conglomerate of the former Soviet Party elite representatives still holding political power, and of criminal gangs committing forcible takeovers, money extortions etc. It is the political elite of the time, as the Ukrainian researcher Sviatoslav Kulchytsky puts it, that bears the lion's share of responsibility for failing to regulate the process legally: "The inadequacy of the new legislation as opposed to economic practice led to a notable weakening and, at times, to a virtual exhaustion of the state's impact upon the economic development. This is how a legal framework backing the criminalization of economic activities was established in Ukraine. Both major and minor officials could claim the "free" property fairly unimpeded by abusing their power»" (Kulchickii, 2001).

The heavily industrialized regions left unprotected by the state, Donbass being exactly the case, turned into a breeding ground for clan-structured oligarchic groups emerging in Ukraine. Ukrainian Historian Volodymyr Golovko defines four basic stages of the large industrial capital development in Ukraine:

1. Fragmenting production facilities of the Soviet type and amassing primary capital (1991-1998);

2. Creation of financial industrial conglomerates (1999-2004);

3. Formation of specialized branch companies (20052009);

4. Monopolization and expansion of foreign capital presence (2009-2013) (Golovko, 2012a).

Large industrial capital formation in Donbas follows the general national pattern.

The transition from the first to the second stage was quite well described by Denis Kazansky: "Train cars with illegal coal were pulled from forgotten stations to various corners of the country and even across the border, but the budgets of mining towns and villages did not receive anything from this flow. Taxes, traditionally, were out of question, and thus, regardless of the increasing populace income and some sort of livening up of the trade and service sector, the infrastructure of the depressive territories continued to degrade and die off. Cities that quite literally stood upon gold deteriorated even faster, became unlivable, while thousands of jackhammers and pickaxes were striking away within its depths, unearthing the precious mineral" (Kazanskii, 2015). The money received by the facility owners never reached the pockets of the actual workers since the unearthed raw materials was sold to foreign buyers for cash, thus evading any documented profits accounting. Such schemes turned into habit while local businesses drifted more and more into the "shadow". To legalize, at least to a certain extent, the newly acquired property, the ex-party functionaries, "red executives" and "new businessmen" initiated the Law of State and Communal Property Rent that granted them prioritized rent of factories and their equipment (Zakon Ukraïni "Pro orendu...", 1992). According to Stepan Davymuku's assessments, "at least 300 objects of property were privatized via rent-to-buy option in Donetsk region, 223 - in Kharkiv region, 180 - in Kyiv region, 172 - in Dniepropetrovsk region etc." (Nosareva, 2000).

The early 1990-ies saw the rise of several influential groups, three of them de facto preceding the so-called 
"Donetsk clan". The first one was led by Zasyadko mine's first director, later Donetsk mayor Yuhim Zviahilsky. The second one was a tandem of Yevhen and Volodymyr Shcherbans who joined Liberal political party. The third group comprised the Donbas Industrial union, with the leading positions taken by Vitalii Haiduk, Serhii Taruta and, further on, by Rinat Akhmetov.

$1992-1993$ is a starting point for "the Donetsk gang's" expansion over Kyiv. The key formula of the Donetsk ideology, attributed to Vitaliy Haiduk, sounded like: "money is made in Donbas, and politics in Kyiv". Another characteristic trait of "the Donetsk gang" came down to the statement that they won't let the strangers into the region: "no matter how hard we fight inside the region, outside we look solid-cast".

The main reason explaining the Donetsk gang successful expansion over Kyiv, specifically in times of Zviahilsky's premiership, was that then president Kravchuk had literally nobody to rely on: he just did not have his own financiers. Meanwhile, the "Donetsk gang" making their first steps into politics and having no idea of how to manage their own region owned considerable capitals. Not only did this pave the way towards their consequent political union, but also (mostly because of lack of political thinking, both general and national-focused) to Kravchuk's ultimate loss of presidential elections in 2004.

To briefly describe the stages of the Donetsk clan's gradual formation, the following important events should be highlighted:

1992-1993 - Yuhim Zviahilsky appointed deputy prime minister under Kuchma's administration and dubsequently promoted to acting prime minister.

1994-1995 - Yevhen Shcherban's rise to the fore to secure Volodymyr Shcherban's election as the head of Donetsk regional administration, consolidation of all primary players of the region, creation of the parliament group "Social-market choice" supporting Yevhen Marchuk for the prime minister and later opposing the successive prime minister Pavlo Lazarenko.

1996-1997 - murder of Yevhen Shcherban and regrouping of powers within the clan, where step by step the primary roles are taken by the members of Donbas Industrial union (at the time Rinat Akhmetov was a de facto representative of that group).

1998-2002 - the representatives of the Donetsk elite gradually engaging into close cooperation with president Leonid Kuchma, driving the Communist and Natalia Vitrenko's Progressive Socialists parties out of the political field. In 2002 they de facto rise to a nation-wide level, assigning a prime minister from their own with a likely aim towards presidency.

2003-2014 - they form into a political power (Party of Regions), which reaches out far beyond the Donetsk region and becomes one of the primary players in Ukrainian politics.

It should be noted that the two rival clan-structured oligarchic groups operating in Ukraine's biggest industrial centers, Dniepropetrovsk and Kharkiv, still dominated the political landscape in the early 1990-ies; however, closer to the end of 1990's, the initiative was slowly taken by "the Donetsk gang".

The modern understanding of the Ukrainian clan structures in contemporary national scientific discourse proves to be oversimplified. Indeed, there is a certain historically determined regional clan affiliation, but, in light of recent events, a more precise clan origins topology is demanded. Four powerful clans were forming in Ukraine at the start of the 1990's:

1) source-based groups (where regional affiliation indeed played a key role);

2) defense industry-based groups with former Komsomol and Party leaders in charge (later on transformed into the first Ukrainian political party: the People's Democratic Party);

3) groups based on legal and secretive agencies (the so-called Kyiv group, mostly known for Victor Medvedchuk and Surkis brothers' activities);

4) Pavlo Lazarenko's attempts at proto-agrarian clan.

As for the Crimean gangs, "Seilem" and "Bashmaky", they also got a chance to form into a strong political group; however, unlike all the others, they did not understand that for further development they would need to go beyond their region.

One of the important reasons for the late Donetsk reps belated engagement in the struggle for reallocating the financial-economic markets and political power in Ukraine was the long-lasting fight between regional mafia groups and fairly lengthy search for the common spokesman to deal with.

The first sign that the Donetsk players were coming back was President Leonid Kravchuk assigning the post of acting prime minister to Yuhim Zviahilsky. Zviahilsky's emergence to a republican level was tied to a streak of miner strikes in 1993. These strikes seem to have been orchestrated by the "red executives" themselves, with the aim to elect "their" prime minister. First Zviahilsky entered Kuchma's administration as the first deputy prime minister, and then, after Kuchma's resignation from the post of prime minister, he took the now vacant spot as the acting prime minister of Ukraine. The assignment of Zvyaginsky, one of the most influential Donetsk clan representatives, was in practice and attempt by Kravchuk to undermine the influence of Dnipropetrovsk.

It is worth to note that Zviahilsky "transferred" the mayoral post of Donetsk to his close colleague Volodymyr Rybak, who later would become one of the founders and ideologists of "Party of Regions".

Zviahilsky's presence in the ministry was brief and had quite unfavorable consequences for him. In August of 1994 Dnipropertrovsk had their revenge with Kuchma winning the early presidential election. In October of 1994, presumably with Kuchma's initiative, the prosecutor general's office opened a criminal case against Yuhim Zviahilsky, suspecting him of excess of authority and large scale stealing. Not waiting around to be arrested, Zviahilsky had to hide from criminal investigation in Israel until 1997. In 1997 the allegations were lifted and he could return to Ukraine (Gusev \& Lashhuk, 2019).

After Zviahilsky's escape to Israel, Donbas was controlled by "young merchants", which were taken under Zviahilsky's wing back in 1992. The cohort of the new "masters" of Donbas included: Yevhen Shcherban, Vitalii Haiduk, Serhii Taruta, Akhat Brahin, Rinat Akhmetov and others.

The period of the early 90 's became the time of one of the most violent criminal feuds on this territory in the 20th century. Still, understanding the establishment of the clan requires taking a look at two crucial murders that had a big effect on the whole story: the murders of Akhat Brahin (Alik Grek) and Eugene Shcherban. 
Akhat Brahin is a person with a quite dark biography, according to some testimonies he made his capital while leading one of the organized crime groups in Donetsk oblast beginning from the middle of 1980's (Kuzin, 2006). So what united Akhmetov and Brahin? According to one version they were distant relatives, however there is no proof of it. It is certain that some time the two spent working together in Donetsk Store №41, where Brahin was the director, and the main source of profit was the selling of deficit goods to tsekhoviks. It is also thought that racket was another source of making money. However, in any case, experienced people say that until the 1990's Brahin's gang had basically no legitimate businesses. Their main income was racket. In this regard the gang did not significantly differ from other organized crime groups of Donetsk ${ }^{2}$

It is impossible to say for certain, however according to a Donetsk journalist this was the connection between Brahin and Akhmetov: "Brahin had the money and contacts, while Akhmetov managed the force aspect of their activities. Simply put, he would drive out and take care of conflict situations. They needed access to government offices. This is precisely when Yanukovich began cooperating with the group, who as the CEO of a big transport company had good contacts in the regional administration. Together they made a beautiful trio" (Orlov, 2003). It is this trio that got the biggest "dividents" after Brahin's murder. However, this story, at least in the context of Yanukovich, raises too many questions. Apparently, Akhmetov was a younger partner (a very close person) to Akhat Brahin. However his role in the structure of Brahin's empire still remains to be fully understood. As for Yanukovich, he as a person with a criminal past and certain connections, while also having connections in special services, which at that time began to get close to the criminal world, must have been in the right place at the right time. There couldn't be talk of any sort of equal partnership.

In 1992-1996 the Donetsk area grew into one of most criminalized regions of the post-Soviet space. According to different estimations, the average monthly statistics of unexposed murders, a lion's share of which belonged to gangland killing, made 25-30 people a month. Many researchers try to reduce Brahin's murder to the elementary fight against Kushnir's gang (Brahin had been the victim of at least two attempts against his life before he was blown up on a stadium). Probably, one should not simplify, because there was a struggle for control over the region and there were always numerous nuances, betrayals and situational agreements in this struggle. By the time of his murder Brahin had become not just a noticeable figure in Donetsk establishment, he obviously started being included in the system of top-10-15 of the most influential people of the region. But later, as it usually happens in similar situations in any point of the world, it became necessary for business development to replace basically criminal leaders with half-criminal or, better yet, nearcriminal ones. Therefore, Brahin's death was mostly predetermined by the evolution of elites' formation in such cases.

After Brahin's assassination on October 15, 1995 on a stadium in Donetsk, the Donetsk Municipal Bank almost

\footnotetext{
${ }^{2}$ «Krestnyj syn». Retrieved from:

https://www.pravda.com.ua/articles/2005/07/5/3011315
}

immediately fell into Akhmetov's hands, and yet in a year Akhmetov became the owner of FC "Shakhtar", and Victor Yanukovych became the vice-governor (Orlov, 2003). Rinat Akhmetov de facto became the legal successor of Brahin's empire.

Another Donetsk "authority" Yevhen Shcherban was assassinated in 1996. Yevhen Shcherban was born on January 18, 1946 in the village of Kostiantynivka in Krasnokutsk district of the Kharkiv area. In 1977 he graduated from Donetsk Polytechnic Institute. On completion of studies he began working at "Kirovska" mine. After working for 10 years at this mine (1977-1988), he took up entrepreneurial activitity - founded "Progress" Cooperative (in 1988), and in a year he organized the Donetsk Regional Production Association "Center". In 1994 he founded the corporation "ATON"3.

Alongside with his entrepreneurial activity, after the proclamation of Ukraine's independence he actively began to develop his political career (he was one of the first in the region to understand the importance of connections in the capital). Already in 1994, after the retirement of Zviahilsky, Yevhen Shcherban became the external adviser of the prime minister of Ukraine Vitalii Masol. And in the same year he was elected as a deputy to Verkhovna Rada of Ukraine ${ }^{4}$.

In 1994 the elections were held for the head of Donetsk regional administration, in which a landslide victory was won by Volodymyr Shcherban, who became a compromise figure for all near-political beau monde of the region.

In Kyiv, Yevhen Shcherban creates in Verkhovna Rada the faction "Social-Market Choice" that mainly united the politicians coming from the Donetsk area. At the same time, Yevhen Shcherban didn't establish good relationship with Leonid Kuchma, so he made his bet on the prime-minister Yevhen Marchuk.

Having a considerable financial capital and political influence, Yevhen Shcherban became one of the most influential figures of Donbas after Brahin's murder. According to one of versions, the duumvirate of Yevhen and Volodymyr Shcherbans (V. Shcherban had no family ties to $\mathrm{Y}$. Shcherban) was then considered the nucleus of the Donetsk financial-industrial clan. Those were the Shcherbans who tried to consolidate everyone around the interests of Donbas, and hence their own financial interests. These processes are described in considerable detail in Volodymyr Shcherban's remembrances "Confessions at bedtime". In particular, in these remembrances he mentions the estimation of that time's situation given by his partner Yevhen Shcherban: "It becomes obvious, that under the slogans of the struggle against mafia and corruption, the systematic weakening of leading business corporations, removal of political and economic leaders in the Donetsk region is taking place aimed at seizing control over the sales market of gas, electric power, oil products. In short, the hidden intervention is going on in the political and economic aspects" (Kushch, 2013).

In our opinion, by that time only the representatives of two most powerful regional clans - "the Dnipropetrovsk"

\footnotetext{
${ }^{3}$ Zhizn i smert Evgenija Shherbanja: zagadki pervogo millardera Ukrainy. Bigmir.net. Retrieved from: http://finance.bigmir.net/business/36633-Zhizn--i-smert--EvgenijaCsherbanja--zagadki-pervogo-millardera-Ukrainy ${ }^{4}$ Shherban Evgenij (2012) Liga. Dosye. Retrieved from: https://file.liga.net/persons/shcherban-evgeniy.
} 
and "the Kyivans" - could be such competitors for "the Donetsk clan". It was such a serious threat, that Yevhen Shcherban openly told about it to his associates: "It won't be long before all key posts in the area (in power structures and state administration) are occupied by the representatives of other regions, and the main energy suppliers and importers of highly marketable commodities will naturally be the firms that represent their interests. And you, the present-day businessmen, and your children will stand in a line for permission to become rich, and you won't be allowed any farther than the tent" (Kushh, 2013).

In 1996 Kuchma gets rid of all the select heads of regional administrations and removes prime-minister Marchuk. On by-elections, Marchuk is elected as a deputy from Kirovohrad area, and he heads the group "SocialMarket Choice" at the behest of Yevhen Shcherban. It was considered at that moment that it was Marchuk who could become a serious counterbalance to Leonid Kuchma in future presidential elections and form the main center of opposition against him. But all these forecasts were ruined after Yevhen Shcherban's assassination on November 3, 1996.

According to one of the versions, the reason for Shcherban's murder lay in his position regarding the struggle with "Dnipropetrovsk clan" through Pavlo Lazarenko's group. This conflict was rooted in the struggle for energy market between the corporations of "the Dnipropetrovsk clan" - the "United Energy Systems of Ukraine" (UESU) and "the Donetsk clan" - "The Industrial Union of Donbas". But UESU did not succeed to take over this part of the market, moreover, by some accounts, it was Lazarenko who persuaded Kuchma to appoint Victor Yanukovych to the vacancy of the governor of the Donetsk area after Shcherban's murder (Mostovaja, 2013).

According to another version voiced by the MP Oleksandra Kuzhel, Shcherban's main conflict was with the Russian company "Itera". She pointed out the absence of conflicts between the companies of Shcherban and Yulia Tymoshenko. "There were no problems with UESU company. I can assume that Yevhen had a conflict with "Itera". And the circumstances of Yevhen Shcherban's shooting indicate that without the special services' assistance not a single killer would be able to carry out this murder. The organization of assassination on such a level is impossible even for people of such a level as Lazarenko, not to mention the gangsters that are now called its organizers and performers"

According to the official version of the Ukrainian law enforcement officers, the murder had been ordered by Pavlo Lazarenko, although he refuted it categorically (Leshchenko, 2011).

After Shcherban's assassination the parliamentary group "Social-Market Choice" began to fall into a decay, and in 1998 it actually grew into a faction of the Party of Regional Revival (later the Party of Regions was formed on its basis), and the main players of the region gradually began to find contacts with Leonid Kuchma and eventually became his basis and support in the region.

In fact, after Shcherban's murder, the representatives of Donetsk go over to Leonid Kuchma's side completely

5 Kuzhel: potribno rozsliduvati, komu pishlo majno Shherbanja. Retrieved from: https://www.radiosvoboda.org/a/24921999.html

ISSN 1728-9343 (Print)

ISSN 2411-3093 (Online) and work for his victory. At this time, after a number of divisions and divergences among local businessmen, the situation gradually emerges in which, when Yanukovych takes the position of the prime minister in 2002, Rinat Ahmetov who by that moment has become the main shareholder of the Party of Regions becomes the central figure in Donetsk.

In terms of political evolution of the clan, as it was already mentioned, in 1998 the fraction of the Verkhovna Rada "Socially marketable choice» ceased to exist. In fact, this meant the end of the Liberal Party of the two Shcherbans and a complete change of the «leadership of the Donetsk clan». The place of the liberals was taken by the fraction of the Party of Regional Revival of Ukraine (PRRU). This party was officially founded on October 26 , 1997. The first chairman of the party was the mayor of Donetsk, Volodymyr Rybak. November 17, 2000, the PRRU was expanded to include the Labor Party, the Political Party "For Wonderful Ukraine", the Solidarity Party of Ukraine, and the All-Ukrainian Retiree's Party. A year later, on March 3, 2001, the PRRU was reorganized into the "Party of Regions", headed by Mykola Azarov as the new chairman of the party ${ }^{6}$. The main electoral base of this party is concentrated in the South-Eastern regions of Ukraine. At the first stages of its formation, the PRRU focused on the support of Leonid Kuchma. In 1999, the PRRU officially supported him in the presidential elections. In the next parliamentary elections in 2002, the "Party of Regions" merged with the presidential bloc "For United Ukraine!", which gave the "Party of Regions" an official opportunity to nominate its candidate Viktor Yanukovych for the position of the Prime Minister of Ukraine.

As for Rinat Akhmetov's acquiring a leading political role, it is worth noting that until about 2000 , the Industrial Union of Donbass (IUD) founded in 1995 in the city of Donetsk, had remained a major campaign in the region (and Ukraine). Vitalii Haiduk, Serhii Taruta and Rinat Akhmetov were the company's main stakeholders. In fact, founding this company was associated with an attempt to consolidate and systematize all possible assets (as a number of assets at that time were not so notable in the legal as in the conceptual frame). Another reason for the creation of the company is opposition to attempts to seize (UESU) energy sector of Donbas by the "colleagues" from Dnipropetrovsk. According to Serhii Taruta, protection against expansion was not a single goal. The main goal of the FIG organization is "to revive" the industrial potential of the entire region. This meant creating conditions for gas supplies to all enterprises in the region without preferences. Then the Industrial Union of Donbass - IUD appeared. In short, it was State Supply and State plan rolled into one. The ideology was to provide payments for gas with commercial products for all enterprises in the region, since the enterprises did not have funds» (Leshchenko, Nayyem, 2013).

After the creation of the IUD, Serhii Taruta was appointed executive director, who had created the foreign trade company "Azovimpex» a year earlier, and therefore had the necessary experience. Other business structures were closely connected with the newly created corporation - «Danko» (Alexander Mamot),

6 Partiya Regionov. Liga. Dosiye. Retrieved from: https://file.liga.net/parties/partiya_regionov 
«Dongorbank» (Rinat Akhmetov) and Evgeny Shcherban's companies.

According to the order of the then governor of the Donetsk region, Vladimir Shcherban, IUD began to supply gas to the region. But the IUD was never able to implement the plan of the governor Shcherban, and had to negotiate with the UESU and buy gas for the region from them, and then resell it. Despite this setback, the IUD continued to increase its influence in the region. And after establishing relations with Kuchma's entourage, IUD gradually built a profitable chain - "coal-coke-metal" and "skelp-pipe-gas". Thanks to new ties with Dnepropetrovsk, IUD was able to directly purchase gas from the Russian "Itera» and sell it to enterprises in the region.

Close cooperation between IUD and Akhmetov continued until 2000 (Guzhva, 2004). Then a decision was made to separate all assets amicably and gradually. There could be several reasons for the separation. It's no secret that working in partnership is always difficult, and this could have provoked Akhmetov's separation. In addition, Akhmetov at that time was already in a status when it was necessary to separate into his own company, which would be his brand. It should not be forgotten that the time for the separation was more than favorable, because the decree of the President of Ukraine Kuchma "On measures to develop the basic sectors of the economy in the Dnipropetrovsk and Donetsk regions" (Pro zahody..., 2000). According to the historian Golovka, this Decree gave the "green light» for the shadow transition of power generating and power supply companies under the control of local elites (Golovko, 2012a: 16). In any case, whatever the motives of Akhmetov, the main consequence of this gap was that he siphoned off all his assets from the IUD and began the development of SCM.

To understand the specifics of doing business at that time and for a better understanding of the specifics of relations between IUD partners, I should quote from an interview with Serhii Taruta: "Zhenya Shcherban invited me to a meeting - "to talk about metallurgy". I'm told that: "Where are you going - this is a hornet's nest." Still, I set my mind to go. There was a young, readhead Rinat, as well as Alik Grek and others. And this is where I saw a huge difference in approaches. Shcherban was already attracted to politics - he realized that it was possible to convert political influence into money. Alik Grek thought about Petrol stations, bases, shops. And Rinat thought globally: how to connect mines with factories, and how to build a production chain. I told him about the need to merge two Metallurgical Plants in Mariupol for synergy. We talked about things that many have not thought about yet ..." (Shvets, 2015).

In 2000, the IUD, according to some estimates, was the most powerful in Ukraine. By the end of 1999, «Industrial Union of Donbass» topped the rating of the most profitable companies in Ukraine with a gross income of 3.8 $\mathrm{UAH}^{7}$.

«System Capital Management» (CKM, System Capital Management, SCM) -the largest diversified financial and industrial group in Ukraine, which is also represented in 7

\footnotetext{
7 "Doneckii klan" uverenno vhodit vo vlast. Ukrainskaja pravda. 2001. 15.08. Retrieved from:: https://www. pravda.com.ua/rus/news/2001/08/15/4362400
}

countries in Europe and North America ${ }^{8}$. SCM's main areas of interest and activities are focused on such: industries as metallurgy and coal mining, power generation, banking and insurance, telecommunications and others.

SCM was founded in 2000 . The main office of the company is located in Donetsk. Oleg Popov became CEO. The main shareholder of the company - Rinat Akhmetov. In various periods, he controlled from $90 \%$ to $100 \%$ of the shares of this company.

The formation of the SCM financial and industrial group began in 2002, after an audit at «Azovstal». Probably, this audit was just a pretext to break off relations with former partners and re-establish a business that would be subordinate only to Akhmetov.

Some of the first assets of which Akhmetov began to develop his business empire were associated with telecommunication systems - TRC «Ukraine», «Digital Cellular Communications of Ukraine». The «Shakhtar» football club, which Akhmetov «inherited» from Bragin, immediately became an important part of SCM. Telecommunications systems and FC «Shakhtar» are insignificant, although known to most Ukrainian citizens, in Akhmetov's business empire. His main fortune must be sought among the enterprises of heavy industry, which he owns or is the owner through figureheads. The most profitable enterprises in this area of his business are, first of all, the mining and metallurgical enterprises of SCM, united in the «Metinvest» group. They smelt 10.8 annually tons of steel, and the share of «Donbass Fuel and Energy Company» (DFEC) in the overall structure of SCM's financial receipts is approximately $22 \%{ }^{9}$.

Significant financial flows of this group pass through one of the largest banks in Ukraine - the First Ukrainian International Bank (FUIB), which was registered by the National Bank of Ukraine on December 23, 1991. In 2011, FUIB merged with another bank - Donmisbank ${ }^{10}$, which was founded jointly by Bragin and Akhmetov in the early 1990 s.

The structure of the holding is quite clearly broken down by the respective industries: «Metinvest» - the mining and metallurgical sector («Krasnodonugol», «Avdeevsky Coke and Chemical Plant», «Azovstal» Metallurgical Plant, «EnaKyivsky Metallurgical Plant», «Khartsyzsk Pipe Plant» and foreign enterprises: «Ferriera Valsider», "Trametal»(Italy), «Promet Steel» (Bulgaria), «Spartan UK» (Great Britain), etc.), «DFEC» energy (Zuivska, Kurakhivska and Luganska thermal power plants), «Farlep-Invest» - telecommunications (TRC «Ukraine», «Vega», «life», newspapers "Segodnya», «Donetskie novosti», "Vecherny Donetsk», etc.), «Esta Holding» - real estate ${ }^{11}$.

Another FIG organized by this group of people in 2000 is "Altcom». According to official data, the founders of this group were Olexander Tislenko and Serhii

\footnotetext{
${ }^{8} \mathrm{https}: / /$ www.scm.com.ua/about

${ }^{9}$ Sistem Kepital Menedzhment (SKM) LIGABiznesInform. Retrieved from: https://file.liga.net/companies/sistem_kepital_menedjment_skm.

${ }_{10}$ PUMB i Dongorbank obyedinilis (2012). Pershij Ukraïnskij Mizhnarodnij Bank. Retrieved from: https://about.pumb.ua/ru/presscenter/news/item/1033-pumb-i-dongorbank-obednalysya.

${ }^{11}$ System Capital Management. Lb.ua. Retrieved from: https://lb.ua/file/company/3459_sistem_kepital_menedzhmen t.html
} 
Pavlichev ${ }^{12}$. According to some reports, this group is under the control of a close associate of Akhmetov, Borys Kolesnikov, but Kolesnikov himself denies this connection.

\section{Conclusions}

Thuswise, the Soviet Union collapse led to a profound economic ties disbalance between the Donbass largest industries and the raw material suppliers or local product consumers from the former USSR republics. The legislative gap in terms of state-planned to market economy transfer resulted in chaos and proxy battles initiated by paracriminal structures deliberately or incidentally left out of the local law enforcements control. To secure the industries' stable functioning, the new owners would engage the former Soviet Party elite representatives possessing at least basic managerial experience to run the enterprises.

With the gradual development of legal grounds for privatization and the law enforcements capacity regained, the new owners of the assets grabbed early in the 1990ies have launched the process of their incomes and status legalization. One of the ways the Donetsk clan's juniors (Rinat Akhmetov, Volodymyr and Yevhen Shcherban, Serhii Taruta, Vitalii Hayduk, Victor Nusenkis, Borys Kolesnikov, Victor Yanukovych) have taken to acquire legal status was that of the financial industrial groups' establishment.

An important factor contributing not only to the Donetsk clan's sustainability throughout the turbulent 1990ies, but also to its gradual nation-wide expansion was their making a rather successful bit for power: their own political party, the Regions Party, served to deliver their ideology to the target electoral groups of Southern and Eastern regions of Ukraine.

To sum it up, three key stages can be defined in the Donetsk clan's gradual development throughout the 1990-ies and up to the 2000-ies: the first one, marked by chaos and mafiosi wars (early 1990-ies); the second one, that of consolidation and driving the "old guards" out of the regional political and economic field (1995 - 1999); and the third one, that of the ultimate establishment of FIGs pursuing their own economic and political interests (early 2000-ies).

\section{REFERENCES}

Adamovich, S.V. (2007) Dialog mizh Galichinoju i Donbasom u period rozpadu SRSR. Stosunki Skhodu ta Zakhodu Ukraine: subjekty, interesy, tsinnosti. Lugansk: Znannja, 10-20. (in Ukrainian)

Adamovich, S.V. (2009) Dijalnist Narodnogo Ruhu Ukraïni v Donbasi v umovah zdobuttia Ukrainoyu nezalezhnosti. Narodniij Rukh Ukrainy: mistse $v$ istorii ta polititsi (Proceeding Papers). Odesa: Astroprint, 12-16 (in Ukrainian)

Golovko, V. (2012a). Oligarkhi iz goroda roz. Stanovlenie $i$ razvitie krupnogo kapitala Donbassa (1991-2014 gg.). Kyiv: Instytut istorii Ukrainy NAN Ukrainy (in Russian)

Golovko, V. (2012b) Ukrainski finansovo-promislovi grupy v modernizatsiynykh protsesah 1991-2009 rr. Kyiv: Institut istorii Ukrainy NAN Ukrainy (in Ukrainian)

Gusev, G., Lashhuk, T. (2019, Julay, 11 Z parlamentu yde Yukhym Zvyahilskyy - stariyshyna "donetskoho klanu» deputat vosmy sklykan Verkhovnoyi Rady. Babel. Retrieved

12 "Altkom" - odna z najbilshih ukrainskikh finansovo-promislovih grup. RBK-Ukraïna. Retrieved from: https://www.rbc.ua/ukr/tag/altkom-4a001f4e638a9.

ISSN 1728-9343 (Print)

ISSN 2411-3093 (Online) from:

https://babel.ua/?utm_source=page\&utm_medium=main

Guzhva, I. (2004) Deti gaza i stali Jekspert ONLINE. Retrieved from: https://expert.ru/expert/2004/38/38ex-fpg_28421

Kazanskii, Denis (2015). Chorna lykhomanka: nelegalnyi vydobutok vugillia na Donbasi. Kyiv: Tempora. (in Ukrainian)

Kononov, I.F., Kononova, N.B., Denshhik, V.A. (2001). Krizis $i$ samoorganizaciya: Shakhterskiye goroda Donbassa v period restrukturizacii ugolnoj promyshlennosti: socialnoye $i$ ekologicheskoye izmerenija. Lugansk: Alma-mater. (in Russian)

Kulchitskii, S.V. (2001). Zakonomirnosti derzhavotvorchogo procesu u nezalezhnij Ukrainy. Kyiv: In-t istoriï Ukraïni NAN Ukrainy.

Kushch, L. (2013). Donbass 90-kh: raspredelenie biznesa i krovavye posledstvija [Elektronnij resurs] / Lina Kushh. BBC News. Ukraine. Retrieved from: https://www.bbc.com/ukrainian/ukraine_in_russian/2013/01/130124_ru_s_donbass_shcherban_business_90_ye ars.

Kuzin, S. (2006). Donetskaya mafiya. Antologiya. Kiev: Poligrafkniga. (in Russian)

Kuzio, T. (2014). Crime, politics and business in 1990s Ukraine. Communist and Post-Communist Studies. 47: 195-210. DOI: https://doi.org/10.1016/j.postcomstud.2014.04.011

Kuzio, T. (2015). Rise and Fall of the Party of Regions Political Machine. Problems of Post-Communism. 62(3): 174-186 DOI: https://doi.org/10.1080/10758216.2015.1020127

Leshchenko, S. (2011, December, 11). Ubyvstvo Evgena Shherbanja. Oficiyna versiya. Ukrainska pravda. https://www.pravda.com.ua/rus/articles/2011/12/9/6826576/ (in Ukrainian)

Leshchenko, S., Nayyem, M. (2013, February, 8). Sergej Taruta: Kogda ubili Shherbanja, u nas ne bylo problem s EjeSU. Ukrainskaja pravda. Retrieved from: https://www.pravda.com.ua/rus/articles/2013/02/8/6983135/ (in Russian)

Mostovaja, Ju. (2013, January, 25). Prikazano: vyzhat! Zerkalo nedeli. Retrieved from: https://zn.ua/internal/prikazanovyzhat.html (in Russian)

Nosareva, L. (2000, April, 7). Stepan Davymuka: "Legalnaja privatizacija - eto realnyi put borby s korrupciej". Zerkalo nedeli. Retrieved from: https://zn.ua/property/stepan_davymuka_legalnaya_privatiza tsiya eto realnyy put borby s korruptsiey.html. (in Russian)

Orlov, A. (2003, January, 13). Parni iz doneckoy gruppirovki. Chast 1. Ukraina kriminalnaja. Retrieved from: https://cripo.com.ua/investigations/p-1150/ (in Russian)

Pro orendu derzhavnogo ta komunalnogo majna: Zakon Ukrainy. (1992). Vidomosti Verhovnoyi Rady Ukrainy, № 30, st.416. Retrieved from: https://zakon.rada.gov.ua/laws/show/226912\#Text (in Ukrainian)

Pro zahody shhodo rozvytku bazovih galuzej ekonomiki $v$ Dnipropetrovskyi ta Doneckui oblasiakh. Ukaz Presidenta Ukrainy vid 27.01.2000. Retrieved from: https://zakon.rada.gov.ua/laws/show/100/2000\#Text

Shvets, E. (2015). Sergij Taruta: "Rinat bilshe ne oligarh. A ja bankrut. Lb.ua. Retrieved from: https://lb.ua/news/2015/01/05/290927 sergey taruta rinat bolshe.html (in Ukrainian)

Zimmer, K. (2006) Machteliten im ukrainischen Donbass. Bedingungen und Konsequenzen der Transformation einer alten Industrieregion. Münster: LIT, 237 s. (in German) 
Вадим Денисенко,

Запорізький національний університет (Запоріжжя, Украӥна)

e-mail: vifuture@gmail.com,ORCID0000-0003-4317-2884

\section{КОНСОЛІДАЦІЯ ДОНЕЦЬКИХ ФІНАНСОВО-ПРОМИСЛОВИХ ГРУП У 1990-x - 2000-x POKAX}

Розкриваються процеси формування потужних фінансових та індустріальних об'єднань на території Донбасу протягом 1990-х рр. Досліджено роль шахтарського руху у здобутті незалежності України, його подальша еволюція та вплив на формування регіональних еліт. Відзначено, що після проголошення Україною незалежності статус Донбасу виріс, в тому числі через концентрацію в цьому регіоні паливних ресурсів, необхідних для забезпечення держави паливно-енергетичними ресурсами. Першим представником донецьких еліт, що отримав високу посаду в Києві, став Юхим Звягільський, колишній директор шахти імені Засядька. Ключовим моментом його зростання стала співпраця з Президентом України Леонідом Кравчуком, який шукав союзників для боротьби з дніпропетровським кланом. Обґрунтовано авторську класифікацію фінансово-промислових груп в Україні 1990-2000-х рр.: 1) сировинні (побудовані навколо видобутку вугілля та руди, характерні для Донбасу); 2) комсомольсько-партійні на основі ВПК; 3) юридично-спецслужбівська група (найвідомішими представниками стали Віктор Медведчук та брати Суркіси); 4) протоаграрний клан Павла Лазаренка. Описано становлення корпорацій «Систем Кепітал Менеджмент», «Індустріальний союз Донбасу», «Альтком» та роль Ріната Ахметова, Сергія Тарути, Віталія Гайдука, Бориса Колеснікова та інших впливових осіб з Донбасу. Розкрито особливості виникнення цих груп: ключові виробничі активи, банківські установи, юридичний статус, експансія в інші регіони та за кордон. Охарактеризовано перехід від «старої» генерації донецьких еліт, тісно пов'язаної з кримінальними колами, до «нової», заснованої на легалізації отриманих статків у вигляді фрінансово-промислових груп та міжнародного бізнесу. Виокремлено три головні стадії формування донецького клану: 1) «мафіозні війни» (перша половина 1990-х рр.); 2) консолідація і витіснення «старої гвардії» із політичного та економічного поля регіону (1995-1999 рр.); 3) остаточне оформлення ФПГ із власними економічними i політичними інтересами (початок 2000-х рр.). Доведено, що однією 3 причин запізнілого включення «донеччан» у боротьбу за перерозподіл фінансово-економічних ринків та політичної влади в України була довготривала боротьба серед мафіозних груп регіону і пошуки виразника інтересів.

Ключові слова: Донбас; регіональні еліти; фрінансово-промислові групи; олігархи; приватизація; Рінат Ахметов; Сергій Тарута; Борис Колесніков.

(C) Vadym Denysenko

Надійшла до редакції: 13.09.2020

Прийнята до друку: 01.11.2020 